\title{
Addendum to: Deep-sequencing of dsRNAs recovered from mosaic-diseased pigeonpea reveals the presence of a novel emaravirus: pigeonpea sterility mosaic virus 2
}

\author{
Toufic Elbeaino $^{1} \cdot$ Michele Digiaro $^{1} \cdot$ Mangala Uppala $^{2} \cdot$ Harikishan Sudini $^{2}$
}

(C) Springer-Verlag Wien 2015

The authors would like to underline that the six complete RNA sequences of the novel emaravirus PPSMV-2 described in the paper entitled "Deep sequencing of dsRNAs recovered from mosaic-diseased pigeonpea reveals the presence of a novel emaravirus: Pigeonpea sterility mosaic virus 2", proposed for publication on 25 February 2015 and accepted in Archives of Virology on 28 May 2015 (DOI 10.1007/s00705-015-2479-y), were submitted to the European Nucleotide Archive (C EMBL-EBI) on 21 February 2013, as illustrated in the information related to the following accession numbers: HF912243-
HF912246, HG939489, HG939490. Successively, sequences of some partial (RNA3 and RNA4) and complete (RNA2) RNAs of another emaravirus (accession numbers: LM652701, LM652703; NC_026471) were deposited in GenBank $^{\circledR}$ by authors Kumar S., Subbarao B. L., Zaidi A. A. and Hallan V. in June 2014 and February 2015, which showed high identity with those already deposited for PPSMV-2. This represents a further evidence on the existence of a second emaravirus infecting pigeonpea plants affected by sterility mosaic disease.

Toufic Elbeaino

elbeaino@iamb.it

1 Istituto Agronomico Mediterraneo, Via Ceglie 9,

70010 Valenzano, BA, Italy

2 International Crops Research Institute for the Semi-Arid

Tropics (ICRISAT), Hyderabad, Telangana, India 